\title{
A Gas Chromatographic Method for the Determination of the Fungicide Chlorothalonil in Tomatoes and Cucumbers and its Application to Dissipation Studies in Experimental Greenhouses
}

\author{
Márcia H. S. Kurz, ${ }^{a}$ Fábio F. Gonçalves, ${ }^{a}$ Martha B. Adaime, ${ }^{a}$ Ivan F. D. da Costa,${ }^{b}$ Ednei G. Primel \\ and Renato Zanella*,a
}
${ }^{a}$ Departamento de Química, ${ }^{b}$ Departamento de Defesa Fitossanitária, Universidade Federal de Santa Maria, 97105-900 Santa Maria-RS, Brazil

'Departamento de Química, Fundação Universidade Federal do Rio Grande, 96201-900 Rio Grande-RS, Brazil

\begin{abstract}
Desenvolveu-se e validou-se um novo método para avaliar os níveis de resíduo e a dissipação do fungicida clorotalonil em tomates e pepinos cultivados em estufas experimentais. Os vegetais foram submetidos a uma única pulverização com clorotalonil em meia dose, dose recomendada e dobro da dose. Os resíduos de clorotalonil foram extraídos em sistema Ultra-Turrax empregando acetato de etila na presença de sulfato de sódio anidro e determinados por cromatografia gasosa com detecção por captura de elétrons. As curvas analíticas foram lineares de 0,005 a 5,0 mg L-1, com coeficiente de determinação maior que 0,995 . Os ensaios de precisão fornecem resultados aceitáveis com valores de RSD abaixo de $10,5 \%$ e recuperações entre 92,2 e 114,5\% para tomate, e entre 86,2 e 103,3\% para pepino, ambos obtidos para níveis de fortificação 0,028, 0,28, 2,8 e 5,0 $\mathrm{mg} \mathrm{kg}^{-1}$. A interpretação estatística dos níveis de resíduo indicou um modelo de primeira ordem para o comportamento da dissipação do clorotalonil. O tempo médio de meia-vida para o tratamento na dose recomendada, nos dois anos experimentais, foram 8,8 dias para tomate e 1,6 dia para pepino. A taxa mais elevada da diminuição de resíduos de clorotalonil em pepino é devida, principalmente, à taxa de crescimento mais elevada deste vegetal com relação ao tomate. O método desenvolvido provou ser eficiente para a determinação de resíduos de clorotalonil em tomate e pepino até o nível de $0,02 \mathrm{mg} \mathrm{kg}^{-1}$, permitindo avaliar o risco da exposição do consumidor.
\end{abstract}

A new method to evaluate the levels of residue and the dissipation of chlorothalonil fungicide in tomatoes and cucumbers grown in experimental greenhouses was developed and validated. The vegetables were submitted to a single spraying with chlorothalonil at half, equal to and double of the recommended dose. Chlorothalonil residues were extracted in Ultra-Turrax system using ethyl acetate in the presence of anhydrous sodium sulphate and determined by gas chromatography with electron capture detection. The analytical curves were linear from 0.005 to $5.0 \mathrm{mg} \mathrm{L}^{-1}$, with coefficient of determination higher then 0.995 . The assays provide acceptable results with RSD values below $10.5 \%$ and recoveries were between 92.2 and $114.5 \%$ for tomatoes, and between 86.2 and $103.3 \%$ for cucumbers, both obtained from spiked samples at $0.028,0.28,2.8$ and $5.0 \mathrm{mg} \mathrm{kg}^{-1}$ levels. Statistical interpretation of residue levels fitted to a first-order model for the dissipation behavior of chlorothalonil. The mean half-life after treatments at the recommended dose, in the two experimental years, was 8.8 days for tomatoes and 1.6 days for cucumbers. The higher decrease rate of chlorothalonil residues in cucumbers is mainly due to the higher growth rate of this vegetable relative to tomato. The developed method has proven to be efficient for the determination of chlorothalonil residues in tomatoes and cucumbers with a limit of quantification of $0.02 \mathrm{mg} \mathrm{kg}^{-1}$ level, permitting to evaluate the risk of consumer exposure to these residues.

Keywords: chlorothalonil, tomatoes, dissipation, cucumbers, GC-ECD

\section{Introduction}

Chlorothalonil (tetrachloroisophtalonitrile class) is an effective foliage-protector against a broad range of

*e-mail: rzanella@base.ufsm.br plants pathogens attacking many crops, including fruits, vegetables and cereals. Available since 1964, it has been used worldwide to reduce growth rates and sporulation of fungi. ${ }^{1}$ The chemical structure of fungicide chlorothalonil is demonstrated in the Figure 1. Commercially available as $\mathrm{Bravo}^{\circledR}$, Daconil $^{\circledR}$ or Bravonil $^{\circledR}$, it shows low toxicity, 
with $\mathrm{LD}_{50}$ for rats (oralapplication) of $10000 \mathrm{mg} \mathrm{kg}^{-1}$ and of short persistence in the environment. ${ }^{2}$ It is widely used in Brazil principally in tomatoes and cucumbers. The Maximum Residue Limit (MRL) for chlorothalonil in tomatoes and cucumbers established in Brazil are 1.0 and $0.1 \mathrm{mg} \mathrm{kg}^{-1}$ respectively, with a preharvest interval of 7 days. ${ }^{3}$ The Codex Alimentarius Commission ${ }^{4}$ and the Food and Drugs Administration (USA) ${ }^{5}$ established a MRL of $5 \mathrm{mg} \mathrm{kg}^{-1}$ for chlorothalonil in both vegetables. However the European MRL for chlorothalonil was fixed in $0.01 \mathrm{mg}$ $\mathrm{kg}^{-1}$ for both vegetables. ${ }^{6}$<smiles>N#Cc1c(Cl)c(Cl)c(Cl)c(C#N)c1Cl</smiles>

Figure 1. The chemical structure of chlorothalonil.

Greenhouse production of crops normally requires applications of fungicides. Greenhouse cultivation eliminates the rain action and partially the action of the sun in the reduction of used product residues. Thus, information about the persistence of these residues is important for the quality of products and to prevent public health problems. The average residue level of any pesticide in fruit and vegetables depend primarily on the application rate of its active ingredient. Since the fungicides are applied in the end of the growth stage, the yield residues may be higher than those accepted by the specific regulations. ${ }^{7}$

Because the fate of pesticides under normal environmental conditions is controlled mainly by temperature, humidity and light intensity, it is not possible to predict their fate under the environmental conditions from tropical countries like Brazil. This is particularly true for chlorothalonil, which is widely used in Brazil, and a literature search indicates that field degradation kinetics of this pesticide on vegetables grown in greenhouses is not available. The determination of the pesticide's fate on vegetable is very important since this will greatly affect the effectiveness of sprayed pesticides on plants, the preharvest interval and the amounts of residue on vegetables at time of harvest. ${ }^{8}$

Chlorothalonil has been determined in different matrices such as water, fresh products and vegetables ${ }^{9-11}$ by different chromatographic methods. ${ }^{12-18}$ Multiresidue methods such as Luke and Mills have been used for determination of chlorothalonil in fruits and vegetables. ${ }^{13,16}$ However, these methods generally require several steps before obtaining a clean extract.
The dissipation parameters for vegetables grown in greenhouses were studied for different pesticides, such as, methomyl in tomatoes and green beans, ${ }^{19}$ chlorpyrifos in oranges,${ }^{20}$ fenthion in olives, ${ }^{21}$ pyridaben and tralomethrin in peppers, ${ }^{22}$ endosulfan and deltamethrin in tomatoes, ${ }^{23}$ benzoylphenylurea insecticides in peppers and zucchinis, ${ }^{24}$ azoxystrobin, pyrimethanil, cyprodinil, and fludioxonil in tomatoes. ${ }^{25}$ The dissipation behavior of tetraconazole, ${ }^{26}$ and endosulfan ${ }^{27}$ was evaluated in cucumbers, peppers and cherry tomatoes grown in greenhouses.

The objectives of this work were (i) the development and validation of a method for the determination of chlorothalonil in tomatoes and cucumbers and (ii) the establishment of the dissipation of chlorothalonil in tomatoes and cucumbers grown in greenhouses to determine safe preharvest intervals that do not exceed national and international MRL values.

\section{Experimental}

\section{Chemicals}

Standard chlorothalonil (purity 99.7\%) was obtained from Dr. Ehrenstorfer (Augsburg, Germany). Ethyl acetate (pesticide residue grade) was obtained from Mallinckrodt (Phillipsburg, NJ, USA) and anhydrous sodium sulphate of analytical grade from Merck (Rio de Janeiro, RJ, Brazil). Chlorothalonil stock standard solutions were prepared in ethyl acetate and stored at $-5{ }^{\circ} \mathrm{C}$. Working standard solutions were prepared by dilution of the stock solutions with matrix extract. Bravonil ${ }^{\circledR}\left(750 \mathrm{~g}\right.$ chlorothalonil $\left.\mathrm{kg}^{-1}\right)$ was the commercial formulation used for the application in tomatoes and cucumbers grown in greenhouses.

\section{GC-ECD analysis}

The analysis was performed on a Varian gas chromatograph (GC) Model 3800 equipped with an auto sampler model 8200, an electron capture detector (ECD) and a DB-5 (30 m x $0.25 \mathrm{~mm}$ i.d., $0.25 \mu \mathrm{m}$ film thickness) fused-silica capillary column. The standard split/splitless injector was used for splitless injection at $270{ }^{\circ} \mathrm{C}$ with an injection volume of $1 \mu \mathrm{L}$. The ECD detector was maintained at $300{ }^{\circ} \mathrm{C}$, with the make-up gas nitrogen flow-rates at 30.0 $\mathrm{mL} \min ^{-1}$. The oven temperature program was $80{ }^{\circ} \mathrm{C}$ for $2 \mathrm{~min}$, ramped to $290{ }^{\circ} \mathrm{C}$ at $15^{\circ} \mathrm{C} \mathrm{min}{ }^{-1}$, maintained for 2 min. The carrier gas was helium at a head pressure of 18 psi resulting in a flow-rate of $1.5 \mathrm{~mL} \mathrm{~min}^{-1}$ at $80^{\circ} \mathrm{C}$. Under the chosen conditions, chlorothalonil presented an average retention time of $12.4 \mathrm{~min}$. A Star Workstation 6.0 system from Varian was used for data acquisition. 


\section{Extraction and analytical procedure}

Extraction of chlorothalonil residues from tomatoes was carried out according to the following procedures: $25 \mathrm{~g}$ of chopped and homogenized sample was extracted for $1 \mathrm{~min}$ into a Ultra-Turrax mixer at 20,000 rpm with $50 \mathrm{~mL}$ of ethyl acetate and $25 \mathrm{~g}$ of sodium sulphate, previously heated in oven at $600{ }^{\circ} \mathrm{C}$ for $4 \mathrm{~h}$. The upper layer was transferred to a flask and the residue of this extraction was re-extracted with another $50 \mathrm{~mL}$ of ethyl acetate. The combined extract was transferred to a $100 \mathrm{~mL}$ volumetric flask and the volume was completed with the same solvent. Then an aliquot of $10 \mathrm{~mL}$ was centrifuged for $10 \mathrm{~min}$ at $4000 \mathrm{rpm}$ and $1 \mu \mathrm{L}$ of extract was directly injected in the gas chromatograph without any further clean up.

\section{Validation of the analytical method}

The validation involved a procedure which tested the analytical curves linearity, limits of detection (LOD) and quantification (LOQ) and if the method provides adequate precision and accuracy, in terms of recovery. ${ }^{28}$ For the determination of the LOD and LOQ, different concentrations of the standard solution were injected. The lowest concentration, where the signal showed a signal to noise ratio of three and ten, corresponds to the LOD and LOQ, respectively. The analytical curves were constructed by injecting different concentrations $(0.005,0.01,0.05$, $0.1,0.5,1.0,2.5$ and $5.0 \mathrm{mg} \mathrm{L}^{-1}$ ) of standard solutions prepared in pure solvent and in the respective matrix extract. The chlorothalonil recovery study was performed by fortifying tomatoes and cucumbers that have not been treated with pesticides. Chlorothalonil standards solutions in ethyl acetate were added at the four fortification levels: $0.028 ; 0.28 ; 2.8$ and $5.0 \mathrm{mg} \mathrm{kg}^{-1}$. After evaporation of the solvent, the sample was then extracted as described above and analyzed by GC-ECD. Recoveries were assessed with six replicates of the entire procedure for each level. The precision of the method was evaluated considering the RSD of the recovery assay, in terms of repeatability $\left(\mathrm{RSD}_{\mathrm{r}}\right)$ and intermediate precision $\left(\mathrm{RSD}_{\mathrm{ip}}\right)$, using the same and different days and analysts, respectively.

\section{Greenhouse experimental design}

Experiments were conducted in a greenhouse at the experimental fields of the Federal University of Santa Maria (UFSM), Brazil. The experimental area comprised 16 plots for each vegetable, in which a random block scheme was established with four replicates. Tomato and cucumber plants were sprayed with Bravonil (750 $\left.\mathrm{g} \mathrm{kg}^{-1}\right)$ at 50, 100 and $200 \mathrm{~g}$ per $100 \mathrm{~L}$ water, corresponding to half, equal to and double recommended doses, respectively, with a consumption of $300 \mathrm{~L} \mathrm{ha}^{-1}$. Control samples were cultivated without receiving any treatment with the fungicide. Plants were sprayed on December 2004 and May 2005, for tomatoes and April 2004 and November 2005 for cucumbers. The application of pesticide was executed when about $30 \%$ of the tomatoes were mature and the cucumbers had reached about $5 \mathrm{~cm}$ of length. Four samples were collected at random from each treatment from $1 \mathrm{~h}$ after the application until 13 days after application. As soon as the samples had been picked, they were transferred to the laboratory where they were chopped, blended and analyzed. The sub-samples with approximately $50 \mathrm{~g}$ each were stored in a freezer for control.

\section{Results and Discussion}

\section{GC-ECD determination and method validation}

The chromatograms obtained by GC-ECD corresponding to standard solutions of chlorothalonil prepared in the pure solvent and in the matrix extracts of tomato and cucumber are show in the Figure 2. The chromatograms did not present interference of others compounds in the chlorothalonil retention time in spite of fact the method did not include a clean-up procedure.

The results of the analytical curves obtained with the analytical solutions prepared in pure solvent and in solvent containing the respective matrix extract are presented in Table 1, with coefficient of determination $\left(\mathrm{R}^{2}\right)$ values higher than 0.995 . The detector response was linearly dependent of the concentration up to $5.0 \mathrm{mg} \mathrm{L}^{-1}$. The results demonstrate that the GC-ECD response for chlorothalonil presents matrix effect ${ }^{29,30}$ for the tomato and cucumber, evidenced mainly by the differences in the obtained analytical curves. In this study, the quantification was obtained using the curves prepared in the respective matrix extract to compensate the observed matrix effect. Comparing the responses with the baseline noise the limit of detection was found to be $0.0025 \mathrm{mg} \mathrm{L}^{-1}$ and the limit of quantification was $0.005 \mathrm{mg} \mathrm{L}^{-1}$. The limit of quantification of the method was $0.02 \mathrm{mg} \mathrm{kg}^{-1}$.

Table 1. Data of analytical curves $(y=a x+b)$ and corresponding coefficients of determination for chlorothalonil prepared in matrix extract and solvent in the concentration range of 0.005 to $5.0 \mathrm{mg} \mathrm{L}^{-1}$

\begin{tabular}{lccc}
\hline & $\mathrm{a}$ & $\mathrm{b}$ & $\mathrm{R}^{2}$ \\
\hline Solvent & 88068 & 617 & 0.9967 \\
Tomato matrix & 67867 & 632 & 0.9952 \\
Cucumber matrix & 75214 & 658 & 0.9976 \\
\hline
\end{tabular}




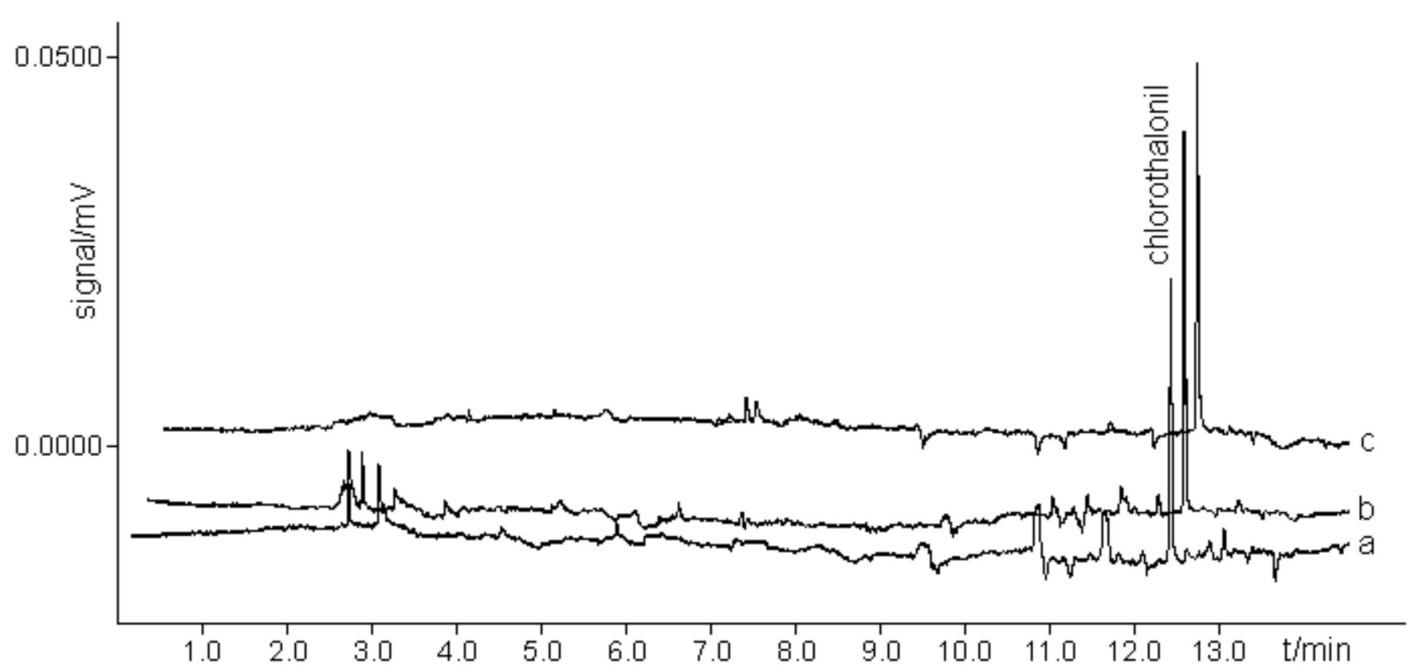

Figure 2. Chromatogram of the standard solutions at the concentrations of $0.1 \mathrm{mg} \mathrm{L}^{-1}$ (a) in pure solvent; (b) in cucumber matrix extract; (c) in tomato matrix extract.

The recoveries, repeatability $\left(\mathrm{RSD}_{\mathrm{r}}\right)$ and intermediate precision $\left(\mathrm{RSD}_{\mathrm{ip}}\right)$ for tomato and cucumber matrix spiked with chlorothalonil at four different levels are summarized in Tables 2 and 3, respectively. The precision ranged from 0.6 to $14.2 \%$. The values are good because all measurements should be within $15 \%$ for all concentrations. The recoveries obtained for chlorothalonil ranged from 86.2 to $114.5 \%$ and are considered satisfactory because all values are between 85 and $115 \% .^{31}$

\section{Dissipation results}

Levels of residue can generally be interpreted by the use of a first-order model, which allows a linearization of data by plotting the natural logarithms of the residues versus time. ${ }^{32}$ Statistical interpretation of chlorothalonil dissipation was done by assuming that the residues degrade with first-order kinetics ( $\ln \mathrm{C}=\ln \mathrm{C}_{\mathrm{o}}-\mathrm{kt}$ ) in which $\mathrm{C}$ is the residual concentration at time $t$ after pesticide application, $\mathrm{C}_{\mathrm{o}}$ is the residual concentration at time $\mathrm{t}=0$, and $\mathrm{k}$ is the dissipation rate constant. The natural logarithms of residue levels, in $\mu \mathrm{g} \mathrm{kg}^{-1}$, were plotted versus time and the results are demonstrated in the Figures 3 and 4.

The straight line that best fit the measured values was computed by regression analysis, and the parameters obtained are shown in the Table 4 . The coefficient of determination $\left(\mathrm{R}^{2}\right)$ values confirms that the degradation behavior of chlorothalonil on tomato and cucumber can be

Table 2. Results of recoveries and precision (repeatibility and intermediate precision) obtained for the four spiked levels of chlorothalonil in tomatoes ${ }^{\mathrm{a}}$

\begin{tabular}{|c|c|c|c|c|}
\hline \multirow{2}{*}{$\begin{array}{l}\text { Level spiked / } \\
\left(\mathrm{mg} \mathrm{kg}^{-1}\right)\end{array}$} & \multicolumn{2}{|c|}{ Repeatibility } & \multicolumn{2}{|c|}{ Intermediate precision } \\
\hline & Recovery / (\%) & $\operatorname{RSD}_{\mathrm{r}} /(\%)$ & Recovery / (\%) & $\mathrm{RSD}_{\mathrm{ip}} /(\%)$ \\
\hline 0.028 & 106.3 & 8.3 & 104.5 & 10.2 \\
\hline 0.28 & 105.7 & 8.8 & 114.5 & 8.6 \\
\hline 2.8 & 92.2 & 4.7 & 111.0 & 1.3 \\
\hline 5.0 & 104.7 & 7.6 & 103.3 & 8.9 \\
\hline
\end{tabular}

${ }^{\mathrm{a}} \mathrm{n}=6$

Table 3. Results of recoveries and precision (repeatibility and intermediate precision) obtained for the four spiked levels of chlorothalonil in cucumbers ${ }^{\mathrm{a}}$

\begin{tabular}{lccrcc}
\hline \multirow{2}{*}{$\begin{array}{l}\text { Level spiked / } \\
\left(\mathrm{mg} \mathrm{kg}^{-1}\right)\end{array}$} & \multicolumn{2}{c}{ Repeatibility } & \multicolumn{2}{c}{ Intermediate precision } \\
\cline { 2 - 3 } \cline { 5 - 6 } & Recovery / $(\%)$ & $\mathrm{RSD}_{\mathrm{r}} /(\%)$ & $\mathrm{RSD}_{\mathrm{ip}} /(\%)$ \\
\hline 0.028 & 86.2 & 1.5 & 8.9 & 87.6 & 3.4 \\
0.28 & 103.3 & 9.4 & 90.1 & 6.9 \\
2.8 & 87.5 & 4.6 & 88.8 & 10.5 \\
5.0 & 101.4 & & 101.1 & 1.9 \\
\hline
\end{tabular}

${ }^{\mathrm{a}} \mathrm{n}=6$ 

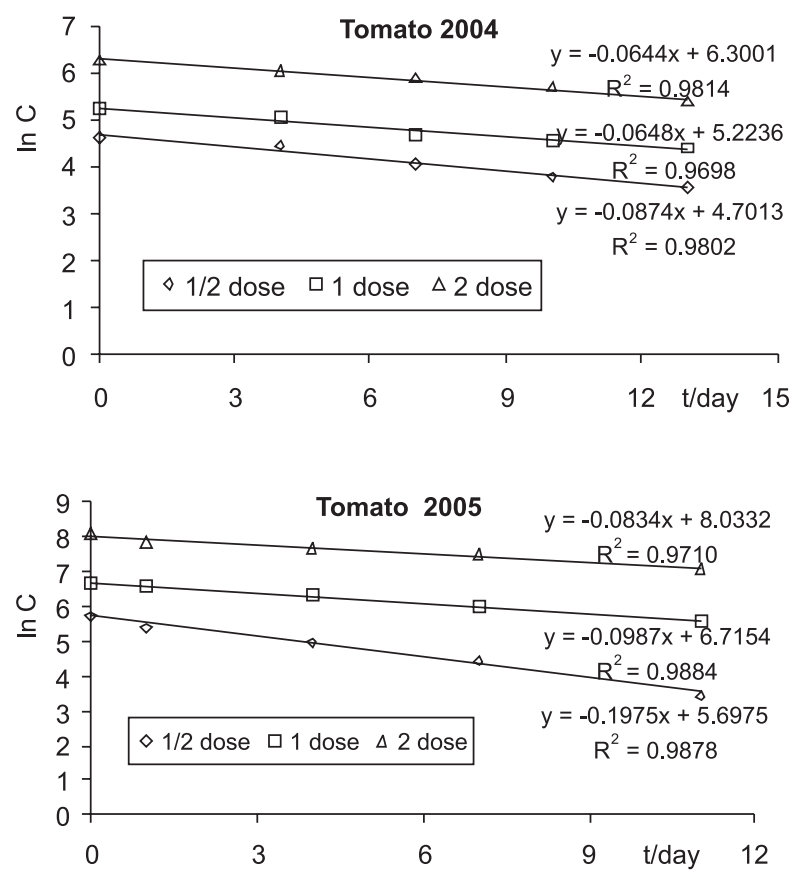

Figure 3. Diminution of chlorothalonil residues $\left(\mu \mathrm{g} \mathrm{kg}^{-1}\right)$ in tomatoes grown in greenhouse (average of four replicates); date of the first sampling: 2004/12/14 and 2005/05/23.
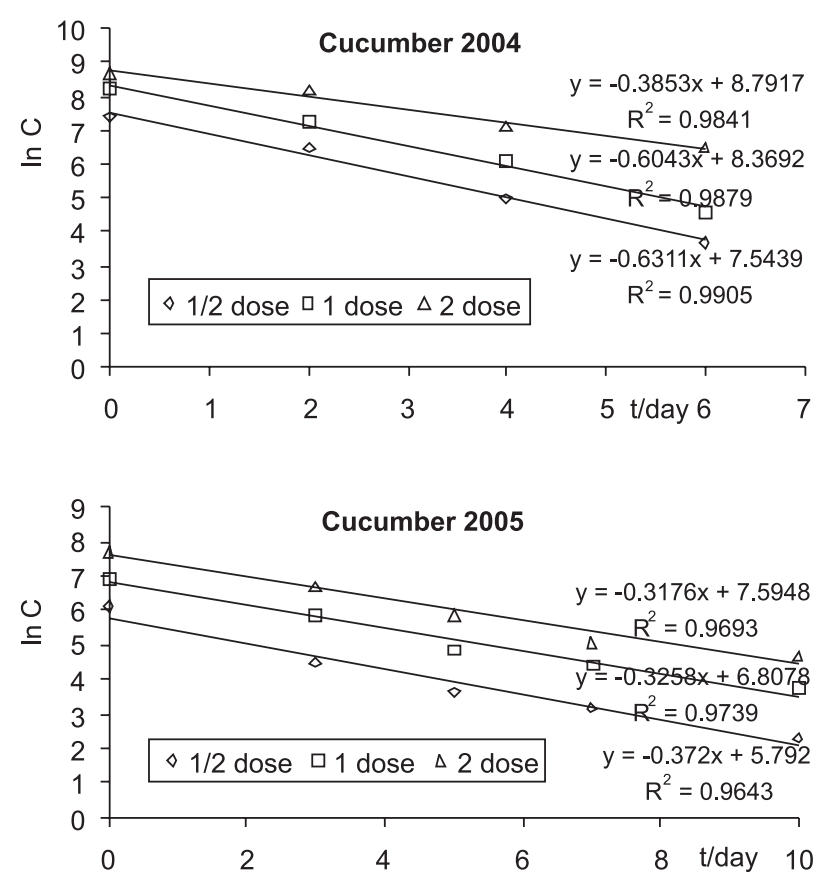

Figure 4. Diminution of chlorothalonil residues $\left(\mu \mathrm{g} \mathrm{kg}^{-1}\right)$ in cucumbers grown in greenhouse (average of four replicates); date of the first sampling: 2004/04/28 and 2005/11/16

Table 4. Parameters of chlorothalonil degradation in tomato and cucumber

\begin{tabular}{|c|c|c|c|c|c|c|}
\hline \multirow{3}{*}{$\begin{array}{l}\text { Parameter } \\
\text { Dose } \\
\text { Month }\end{array}$} & \multicolumn{6}{|c|}{ Tomato } \\
\hline & \multicolumn{2}{|c|}{ Half } & \multicolumn{2}{|c|}{ Recommended } & \multicolumn{2}{|c|}{ Double } \\
\hline & December $^{\mathrm{a}}$ & May $^{\mathrm{b}}$ & December & May & December & May \\
\hline$k /\left(\right.$ days $\left.^{-1}\right)$ & 0.0874 & 0.1975 & 0.0648 & 0.0987 & 0.0644 & 0.0834 \\
\hline $\mathrm{C}_{\mathrm{o}} /\left(\mu \mathrm{g} \mathrm{kg}^{-1}\right)$ & 105 & 302 & 184 & 778 & 532 & 3290 \\
\hline $\mathrm{T}_{1 / 2} /$ (days) & 7.9 & 3.5 & 10.7 & 7.0 & 10.8 & 8.3 \\
\hline $10 \mathrm{~T}_{1 / 2} /$ (days) & 26.3 & 11.7 & 35.5 & 23.3 & 35.8 & 27.6 \\
\hline $\mathrm{R}^{2}$ & 0.9802 & 0.9878 & 0.9698 & 0.9884 & 0.9814 & 0.9710 \\
\hline Parameter & \multicolumn{6}{|c|}{ Cucumber } \\
\hline Dose & \multicolumn{2}{|c|}{ Half } & \multicolumn{2}{|c|}{ Recommended } & \multicolumn{2}{|c|}{ Double } \\
\hline Month & April $^{\text {a }}$ & November $^{\mathrm{b}}$ & April & November & April & November \\
\hline$k /\left(\right.$ days $\left.^{-1}\right)$ & 0.6311 & 0.3720 & 0.6043 & 0.3258 & 0.3853 & 0.3176 \\
\hline $\mathrm{C}_{\mathrm{o}} /\left(\mu \mathrm{g} \mathrm{kg}^{-1}\right)$ & 1632 & 447 & 3758 & 1059 & 6128 & 2224 \\
\hline $\mathrm{T}_{1 / 2} /$ (days) & 1.1 & 1.9 & 1.2 & 2.1 & 1.8 & 2.2 \\
\hline $10 \mathrm{~T}_{1 / 2} /$ (days) & 3.6 & 6.2 & 3.8 & 7.1 & 6.0 & 7.2 \\
\hline $\mathrm{R}^{2}$ & 0.9905 & 0.9643 & 0.9879 & 0.9739 & 0.9841 & 0.9693 \\
\hline
\end{tabular}

${ }^{a}$ year 2004; byear 2005; $\mathrm{C}_{\mathrm{o}}$ correspond to the concentration of fungicide present on vegetable when sampling started.

described as a first-order reaction under the experimental conditions.

In dissipation studies, the establishment of the half-life time $\left(\mathrm{T}_{1 / 2}\right)$ and of the ten half-life time of the residues, that provides information about the persistence of pesticides in crops, are calculated as $\ln 0.5 / \mathrm{k}$ and $\ln 10 / \mathrm{k}$, respectively. ${ }^{33}$
For the recommended dose the average half-lives $\left(\mathrm{T}_{1 / 2}\right)$ were 8.8 days (tomato) and 1.6 days (cucumber), and the average ten half-lives time varied between 29.4 days for tomatoes and 5.4 days for cucumbers, indicating that even after the pre-harvest interval the presence of residues is to be expected in the vegetables. This faster dissipation rate 
of chlorothalonil in cucumbers could be due partially to its higher growth rate in comparison with other vegetables that cause a fast growth dilution effect in the pesticide concentration. This effect also has been observed by other authors ${ }^{8,19}$ who evaluated the dissipation behavior for cucumbers grown in greenhouses.

If we consider the MRL of $5 \mathrm{mg} \mathrm{kg}^{-1}$ established by the USA and by the Codex Alimentarius Regulations for both vegetables, all the residue values found were below the LMR. The MRL of $0.01 \mathrm{mg} \mathrm{kg}^{-1}$ for tomato and cucumber established by the EU Regulations was reached only 15 days after the application for tomato and 10 days for cucumber.

The present study of chlorothalonil dissipation in tomato and cucumber samples cultivated in greenhouse indicate that the pre-harvest interval of 7 days and the dose recommended by the Ministry of Agriculture (Brazil) are appropriated for the application of the fungicide in study, and these conditions should be respected so that the levels of residues become below the limits established by the legislation.

\section{Conclusions}

The developed analytical method allows the determination of chlorothalonil residues in tomatoes and cucumbers with a limit of quantification of $0.02 \mathrm{mg} \mathrm{kg}^{-1}$, permitting to evaluate the risk of consumer exposure to these residues. If necessary, lower limits can be achieved including a volume reduction of the extract before the determination.

The results obtained in the validation step indicated that the proposed method is simple, fast, precise and accurate. The simplicity and the speed of the method are due, mainly, to the fact that a purification step that usually consumes a long time and can introduce errors was not necessary. The efficiency can be demonstrated by the recovery values obtained from tomatoes and cucumbers, which are between 86.2 and $114.5 \%$ with RSD lower than $10.5 \%$.

When the tomatoes and cucumbers were treated at the recommended level, the mean half-lives of chlorothalonil were 8.8 days for tomatoes and 1.6 days for cucumbers. Considering the recommended pre-harvest intervals, the residue levels were within those specified in the Brazilian regulations.

\section{Acknowledgments}

The authors acknowledge the financial support and fellowships from CNPq and CAPES.

\section{References}

1. Ware, G. W.; Whitacre, D. M.; The Pesticide Book, $6^{\text {th }}$ ed., Meister Media Worldwide: Willoughby, Ohio, 2004.

2. Mattern, G. C.; Liu, C.; Louis J. B.; Rosen, J. D.; J. Agric. Food Chem. 1991, 39, 700.

3. http://www.anvisa.gov.br/toxicologia/sia.htm, accessed in February 2008.

4. http://www.codexalimentarius.net/mrls/pestdes/jsp/pest_q-e. jsp, accessed in February 2008.

5. http://www.access.gpo.gov/nara/cfr/waisidx_05/40cfr180_05. html, accessed in February 2008.

6. http://ec.europa.eu/food/plant/protection/pesticides/index en.htm, accessed in February 2008.

7. Sadlo, S.; J. AOAC Int. 2000, 83, 214.

8. Metwally, M.; Osman, M. S.; Al-Rushaid, R.; Food Chem. 1997, 59, 283.

9. Van Doorn, C.; Vink, M.; van der Poll, J. M.; Chromatographia 1995, 40, 458.

10. Gilvydis, D. M.; Walters, S. M.; J. Agric. Food Chem. 1988, 36, 957.

11. Valverde-Garcia, A.; Gonzales-Pradas, E.; Real, A. A.; UreñaAmate, M. D.; Anal. Chim. Acta 1993, 276, 15.

12. Valverde-Garcia, A.; Fernandez-Alba, A. R.; Contreras, M.; Aguera, A.; J. Agric. Food Chem. 1996, 44, 1780.

13. Sannino, A.; Bandini, M.; Bolzoni, L.; J. AOAC Int. 1999, 82, 1229.

14. Lanças, F. M.; Barbirato, M. A.; Galhiane, M. S.; Rissato, S. R.; Chromatographia 1996, 42, 547.

15. Pylypiw, H. M.; Arsenault, T. L.; Thetford, C. M.; Mattina, M. J. I.; J. Agric. Food Chem. 1997, 45, 3522.

16. Gelsomino, A.; Petrovicová, B.; Tiburtini, S.; Magnani, E.; Felici, M.; J. Chromatogr. A 1997, 782, 105.

17. Watanabe, E.; Miyake, S.; Ito, S.; Baba, K.; Eun, H.; Ishizaka, M.; Endo, S.; J. Chromatogr. A 2006, 1129, 273.

18. Mukherjee, I.; Gopal, M.; Fresen. J. Anal. Chem. 1995, 351, 590.

19. Garcia, M. D. G.; Vidal, J. L. M.; Galera, M. M.; Torreblanca, C. R.; Gonzalez, C.; J. AOAC Int. 1997, 80, 633.

20. Montemurro, N.; Grieco, F.; Lacertosa, G.; Visconti, A.; J. Agric. Food Chem. 2002, 50, 5975.

21. Cabras, P.; Garau, V. L.; Melis, M.; Pirisi, F. M.; Spanedda, L.; J. Agric. Food Chem. 1993, 41, 2431.

22. Valverde, A.; Aguilera, A.; Rodriguez, M.; Boulaid, M.; Begrani, M. S.; J. Agric. Food Chem. 2002, 50, 7303.

23. Zerouali, E.; Salghi, R.; Hormatallah, A.; Hammouti, B.; Bazzi, L.; Zaafarani, M.; Fresenius Environ. Bull. 2006, 15, 267.

24. Lopez-Lopez, T.; Martinez-Vidal, J. L.; Gil-Garcia, M. D.; Martinez-Galera, M.; Rodriguez-Lallena, J. A.; Pest Manage. Sci. 2004, 60, 183. 
25. Garau, V. L.; Angioni, A.; Del Real, A. A.; Russo, M.; Cabras, P.; J. Agric. Food Chem. 2002, 50, 1929.

26. Khalfallah, S.; Menkissoglu-Spiroudi, U.; Constantinidou, H. A.; J. Agric. Food Chem. 1998, 46, 1614.

27. Real, A. A.; Valverde-Garcia, A.; Fernandez-Alba, A. R.; Camacho-Ferre, F.; Pestic. Sci. 1997, 51, 194.

28. Ribani, M.; Bottoli, C. B. G.; Collins, C. H.; Quim. Nova 2004, 27,771 .

29. González, F. J. E.; Torres, M. E. H.; López, E. A.; CuadrosRodríguez, L.; Vidal, J. L. M.; J. Chromatogr. A 2002, 966, 155.
30. Hajslova, J.; Zrostliková, J.; J. Chromatogr. A 2003, 1000, 181.

31. Causon, R.; J. Chromatogr. B 1997, 689, 175.

32. Galera, M. M.; Garcia, M. D. G.; Lallena, J. A. R.; Lopez, T. L.; Vidal, J. L. M.; J. Agric. Food Chem. 2003, 51, 5745.

33. Putnam, R. A.; Nelson, J. O.; Clark, J. M.; J. Agric. Food Chem. 2003, 51, 170.

Received: October 22, 2007 Web Release Date: July 14, 2008 